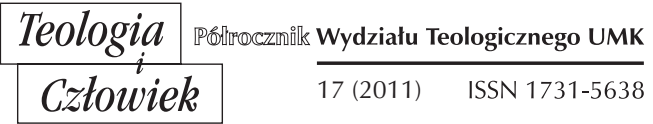

KS. TOMASZ DUTKIEWICZ*

TORUŃ

\title{
JĘZYK JAKO NARZĘDZIE „KŁOPOTLIWE" W UPRAWIANIU TEOLOGII
}

\section{WSTĘP}

Podejmując $\mathrm{w}$ encyklice Fides et ratio problematykę wzajemnego oddziaływania filozofii i teologii, pośród licznych składających się na nią zagadnień, Jan Paweł II zwraca uwagę na problem będącego narzędziem międzyludzkiej komunikacji języka, którym posługuje się zarówno teologia, jak i Magisterium Kościoła w swoim nauczaniu. W szczególności Papież przywołuje kwestię trwałości pojęć, zawartych w formułowanych przez kolejnych następców św. Piotra oraz sobory definicjach, określających właściwe rozumienie prawd wiary. Ojciec Święty wyraża głębokie przekonanie, że ludzki język, mimo swojej ułomności oraz wszelkich uwarunkowań kulturowych i historycznych, jakim podlega, potrafi wyrazić prawdy niezmienne, „przerastające samą historię"1. Jan Paweł II przeciwstawia się $\mathrm{w}$ ten sposób tezom głoszonym przez zwolenników historyzmu, w myśl których wszelka prawda uwarunkowana jest historycznie tak, że to, co jest prawdziwe w jednej epoce, może nie być prawdziwe $\mathrm{w}$ innej ${ }^{2}$.

* Autor jest doktorem filozofii oraz adiunktem w Zakładzie Teologii Fundamentalnej i Religiologii WT UMK w Toruniu.

${ }^{1}$ Zob. Fides et ratio, 95.

2 Zob. tamże, 87. 
Wydaje się, że właśnie refleksja filozoficzna dotycząca języka, ukazująca naturę tego narzędzia, a także zwracająca uwagę na jego ułomności i ograniczenia, przyczynić się może do takiego uprawiania teologii, które pozwoli niezmienne prawdy wyrazić w podlegającym historycznym oraz kulturowym uwarunkowaniom języku tak, by nie narazić na szwank żadnej z istotnych treści Objawienia.

\section{CZY BÓG „TOLERUJE” ZŁO?}

Bezpośrednią inspiracją do podjęcia niniejszych rozważań stało się dla ich autora nieporozumienie, jakie pojawiło się w związku z omawianym na jednym z wykładów problemem relacji pomiędzy wolą Bożą a złem. Sam ten problem, jak powszechnie wiadomo, od wieków nurtował umysły chrześcijańskich myślicieli oraz doczekał się swoich licznych opracowań. Jedno z bardziej znanych stanowi z pewnością, napisana już w czasach nowożytnych przez Gottfrieda Wilhelma Leibniza, słynna Teodycea ${ }^{3}$. Będąc wyrazicielem przekonania, że Bóg stworzył najlepszy z możliwych światów, filozof ten włożył wiele wysiłku, by pomóc adresatom swojego dzieła pogodzić wiarę $\mathrm{w}$ istnienie wszechmocnego i kochającego Ojca $\mathrm{w}$ niebie $\mathrm{z}$ niepokojącym doświadczeniem obecnego $\mathrm{w}$ świecie zła i cierpienia. Sam zaś tytuł jego dzieła wprowadził do obiegowego słownictwa filozoficznego nowy termin, tłumaczony zazwyczaj jako „obrona Boga", obrona przed zarzutami odpowiedzialności za zło doświadczane lub powodowane przez Jego stworzenia ${ }^{4}$.

Rozróżnienie zła fizycznego i moralnego, do którego odwołuje się Leibniz, stanowi nawiązanie do istniejącej już wcześniej tradycji filozoficzno-teologicznej, w nurcie której pozostają również współcześnie uprawiane filozofia Boga i teologia. Klasykiem tej tradycji jest bez wątpienia św. Tomasz z Akwinu, który rozpatrując kwestię relacji pomiędzy wolą Bożą a złem, odróżnia zło moralne ludzkich czynów oraz zło fizyczne, jakim mogą być ból, cierpienie, bądź też niszczące działanie sił natury,

${ }^{3}$ Essais de theodicee sur la bonte de Dieu, la liberté de l'homme et l'origine du mai, 1710. Leibniz zdecydował się napisać swoje dzieło w języku francuskim, tak by mogło ono dotrzeć do możliwie szerokich kręgów ówczesnej europejskiej szlachty.

${ }^{4}$ Termin "teodycea", powstały ze złożenia dwóch greckich słów, theos - „Bóg” oraz dike - „sprawiedliwość", zaczął również funkcjonować jako zamienne określenie filozofii Boga - metafizyki szczegółowej zajmującej się istnieniem, naturą oraz działaniem Bytu Absolutnego. Zob. np. W. Granat, Teodycea, Lublin 1968. 
stwierdzając zarazem kategorycznie, że Bóg „żadnym sposobem nie chce zła moralnego [...] natomiast zła, jakim jest szkoda, czy strata materialna i zła, jakim jest kara, chce, gdy chce jakiegoś dobra, z którym wiąże się dane zło”. Dla przykładu - jak wyjaśnia Akwinata - Bóg „chcąc sprawiedliwości, chce kary; chcąc zachować prawo przyrody, chce, by to lub owo uległo zniszczeniu w sposób naturalny"5.

Stąd też zarówno w wykładzie filozofii Boga, jak i w wykładzie teologii dogmatycznej, zagadnienie relacji woli Bożej do zła zwykło się ujmować syntetycznie w sposób następujący: Bóg nigdy nie chce żadnego zła dla niego samego, jako celu samego w sobie (per se); zła fizycznego może jednak chcieć ubocznie, jako środka prowadzącego do celu (per accidens); zła natomiast moralnego nie chce nigdy, a jedynie na nie przyzwala, toleruje je $\mathrm{e}^{6}$. To właśnie ostatnie $\mathrm{z}$ wymienionych sformułowań stało się przedmiotem wspomnianego wcześniej nieporozumienia, a potem dyskusji, jaka odbyła się po wykładzie.

Wydaje się, że przyczyn zaistniałej kontrowersji doszukiwać należy się przede wszystkim w ewolucji znaczeniowej samego pojęcia tolerancji. W języku łacińskim słowo tolerantia oznacza „wytrzymałość na coś”, sam zaś czasownik tolerare wyraża "cierpliwe, wytrzymałe znoszenie czegoś"7. W tym też znaczeniu w języku polskim słowo „tolerancja” używane jest w naukach biologicznych na określenie zdolności organizmu do znoszenia niekorzystnych warunków środowiska, wpływu szkodliwych substancji itp., czy też w materiałoznawstwie, gdzie pojawia się ono jako synonim odporności materiałów na działanie niszczących je sił, bądź też jako miara możliwych dopuszczalnych odchyleń ich wymiarów, kształtu, składu chemicznego od przewidzianej normy ${ }^{8}$. Warto zauważyć, że we wszystkich powyższych kontekstach słowo „tolerancja” odnoszone jest do czegoś, co traktowane jest niezmiennie jako niekorzystne, szkodliwe, wrogie, w żaden sposób niechciane, ale - właśnie - jedynie „tolerowane”, czyli znoszone.

${ }^{5}$ Św. Tomasz z Akwinu, Suma teologiczna, I, 19, 9.

${ }^{6}$ Podobnie również, na co zwracają uwagę etyka filozoficzna oraz teologia moralna, człowiek może tolerować zło, którego aktem swej woli nie zamierzył i do powstania którego w bezpośredni sposób się nie przyczynia, a które pojawia się wskutek działania pewnej przyczyny zewnętrznej. Mówi się wówczas o złym skutku "tolerowanym”, "dopuszczonym". Por. T. Ślipko, Zarys etyki ogólnej, Kraków 2002, s. 428.

7 Zob. M. Plezia (red.), Stownik łacińsko-polski, Warszawa 1979, t. V, s. 387-388.

${ }^{8}$ Zob. W. Kopaliński, Stownik wyrazów obcych i zwrotów obcojezycznych, Warszawa 1968, s. 762. 
Podobnie też stwierdzenie, w myśl którego Bóg toleruje zło moralne, znaczyć będzie jedynie tyle, że Bóg na to zło przyzwala, szanując wolność swoich stworzeń. Przyzwolenie to wyraża się w praktyce w tym, że Bóg nie podejmuje jakiejś natychmiastowej interwencji, która miałaby na celu uniemożliwienie człowiekowi wyboru zła moralnego i popełnienia grzechu. Fakt ten nie uprawnia jednak w żaden sposób do stwierdzenia, że Bóg zło moralne akceptuje.

Jak można jednak zauważyć, tradycyjne rozumienie słowa „tolerancja" uległo współcześnie daleko idącej modyfikacji. Przypuszczać można, że na ewolucję jego znaczenia w języku polskim swój znaczący wpływ ma popularność języka angielskiego, w którym od jakiegoś już czasu termin tolerance odnoszony jest nie tylko do postawy "cierpliwego znoszenia" cudzych odmiennych poglądów czy zachowań, ale także do postawy wyrażającej się $\mathrm{w}$ ich akceptacji, a także $\mathrm{w}$ rezygnacji $\mathrm{z}$ ich krytyki ${ }^{9}$. Wydaje się rzeczą oczywista, że w tym znaczeniu faktycznie trudno zgodzić się ze stwierdzeniem, iż Bóg zło moralne toleruje, zważywszy na fakt, o którym wyraźnie poucza nas Objawienie, że nienawidzi On grzechu oraz wielokrotnie grzech piętnuje ${ }^{10}$.

\section{JĘZYK JAKO NARZĘDZIE KOMUNIKACJI I NAUKI}

Jednym z popularnych określeń, jakimi zwykliśmy się posługiwać w odniesieniu do człowieka, wskazując na jego wyjątkowość oraz transcendencję $\mathrm{w}$ stosunku do świata przyrody, jest łacińskie wyrażenie homo faber. Współcześnie, w kontekście powyższym, przywoływany bywa również angielski odpowiednik tego określenia, opisujący istotę ludzką jako tool making animal - „Zwierzę wytwarzające narzędzia”. Zdolność tworzenia sobie narzędzi pełni w tym wypadku funkcję różnicy gatunkowej, pozwalającej na ukazanie specyfiki ludzkiego bytu, wyróżniającej go spośród występującego w przywołanym określeniu w funkcji najbliższego rodzaju świata zwierząt ${ }^{11}$.

${ }^{9}$ Zob. Longman Dictionary of Contemporary English, Harlow 1995, s. 1521.

${ }^{10} \mathrm{O}$ Bożej nienawiści wobec grzechu wielokrotnie wspominają teksty biblijne, np. Pwt 12, 31; Jdt 5, 17; Ps 119, 104; Ap 2,6.

${ }^{11} \mathrm{~W}$ myśl swej klasycznej koncepcji definicja zawiera dwa elementy: najbliższy rodzaj oraz różnicę gatunkową (definitio fit per genus proximus et differentiam specificam). Przykładem takiej definicji może być arystotelesowska definicja człowieka jako zoon logikon - „zwierzę rozumne”, przyswojona w późniejszej scholastycznej tradycji jako animal 
Najbardziej „ludzkim” ze stworzonych przez człowieka narzędzi jest język, gdyż sam fakt jego powstania w sposób bezpośredni wskazuje na wyjątkową w świecie przyrody cechę - rozumność. U podstaw języka leży bowiem specyficznie ludzka zdolność myślenia abstrakcyjnego i pojęciowego, w wyniku której cechy wspólne określonej grupy poznanych $\mathrm{w}$ kontakcie zmysłowym przedmiotów, oderwane zostają od pozostałych cech jednostkowo-konkretnych, tworząc to, co zwykliśmy określać mianem "pojęcia”. Pojęcie to zatem nic innego jak utworzony w wyniku procesu abstrakcyjnego myślenia intelektualny obraz istoty rzeczy ${ }^{12}$. By obraz ten mógł stać się przedmiotem międzyludzkiej komunikacji, musi mu zostać przypisany pewien znak materialny ${ }^{13}$. Pojęcie, by mogło być przekazane drugiemu człowiekowi, potrzebuje zatem słowa, które pełnić będzie funkcję jego materialnego odpowiednika. Niezależnie od tego, czy mieć będziemy do czynienia ze słowem pisanym, czy też mówionym, w każdym z tych przypadków chodzić będzie niezmiennie o coś materialnego, co podpada pod ludzkie zmysły - druk, litery na tablicy czy na ekranie komputera, postrzegane przy pomocy wzroku, wypukłości liter alfabetu Braille'a rozpoznawane poprzez dotyk opuszkami palców, fala akustyczna wychwytywana przez narząd słuchu, itd. Warto zauważyć, że o ile samo pojęcie posiada charakter, rzec można, międzynarodowy, jako że ten sam intelektualny obraz np. psa, posiadać będzie zarówno Polak, Rosjanin, jak i Niemiec, o tyle stanowiący część składową danego języka znak tego pojęcia będzie w poszczególnych przypadkach różny, tak że pierwszy z nich wskazując na czworonoga powie: „pies”, drugi: „sobaka”, trzeci zaś: „der Hund”"14. Wielość języków wynikać zatem bę-

rationale. Arystoteles omawia niniejsze zagadnienie w swoich Analitykach wtórych. Zob. G. Reale, Historia filozofii starożytnej, tłum. I. Zieliński, Lublin 1996, t. II, s. 536. Opracowaną przez Arystotelesa teorią definiowania pojęć i odpowiadających im nazw posługuje się również współczesne językoznawstwo. Zob. I. Bobrowski, Zaproszenie do językoznawstwa, Kraków 1998, s. 20-21

${ }^{12}$ Przez istotę rzeczy rozumiemy to, bez czego dana rzecz, nie byłaby tym, czym jest. Do istoty np. samochodu należeć będą silnik oraz dwa "ślady" kół, nie zawierają się natomiast w niej - marka, kolor, wielkość, moc silnika itp. Istota rzeczy jest podstawą ujęć definiujących daną rzecz, definicja to właśnie określenie istoty rzeczy.

${ }^{13}$ Określenie „znak materialny” stanowi pleonazm, gdyż do samej natury znaku należy jego materialny charakter. Zob. Z. Hajduk, Ogólna metodologia nauk, Lublin 2000, s. 19. Użycie tego określenia w konkretnym przypadku ma na celu uzyskanie większej wyrazistości tekstu.

${ }^{14}$ W każdym znaku wyróżnić można dwie warstwy: znaczącą (formę znaku) w tym wypadku będzie nią sekwencja dźwięków, bądź też ciąg liter, różnych w zależ- 
dzie z wielości systemów znaków umownych, utworzonych w różnych grupach społecznych $\mathrm{w}$ celu porozumiewania się.

Stworzony przez człowieka w celach komunikacji język stał się również podstawowym narzędziem uprawiania nauki. Każda z dyscyplin naukowych w mniejszym lub większym stopniu wykształciła właściwą sobie terminologię, by korzystając z niej móc opisywać badany przez siebie przedmiot oraz przekazywać wyniki swoich badań. W ten sposób twierdzenia formułowane $\mathrm{w}$ ramach tych dyscyplin realizują istotny w nauce wymóg tzw. intersubiektywnej komunikowalności. Komunikowalność ta zakłada, że rezultaty prowadzonych poszukiwań, badań, czy też analiz, mogą zostać przekazane w sposób zrozumiały osobie posiadającej niezbędne kwalifikacje umysłowe ${ }^{15}$.

Rozpatrując kwestię źródeł terminologii naukowej, zwrócić należy uwagę na dwa zasadnicze sposoby tworzenia słownictwa naukowego. Pierwszy z nich polega na pozyskiwaniu wyrażeń z języka potocznego oraz ich swoistej redefinicji, która sprawia, że znaczenia tego samego słowa $w$ języku potocznym oraz w języku danej nauki różnić się będą pomiędzy sobą ${ }^{16}$. Proces ten przyczynia się również do powstawania rozbieżności znaczeń jednakowo brzmiących terminów, wykorzystywanych przez różne dyscypliny naukowe ${ }^{17}$. Drugim sposobem wzbogacania

ności od języka, oraz znaczoną (treść znaku) - jest nią zbiór przedmiotów odpowiadających temu znakowi (wspólny odpowiadającym sobie znakom występującym w różnych językach). Zob. I. Bobrowski, Zaproszenie do językoznawstwa, Kraków 1998, s. 44.

${ }^{15}$ Chodzi tutaj, rzecz jasna, o osobę odpowiednio uzdolnioną, która przeszła stosowne przygotowanie. Większość tekstów o charakterze naukowym może się wydać niezrozumiałą dla laika, nie rozumiejącego zawartej $w$ niej terminologii. Znamiennym jest fakt, że tzw. dzieła szkolne Arystotelesa, stanowiące owoc jego wykładów, przeznaczone dla uczniów Perypatu, zwykło się określać mianem „ezoterycznych”, odróżniając je w ten sposób od dzieł literackich Stagiryty, przeznaczonych dla szerszego kręgu odbiorców. Wydaje się, że nie tylko metafizyka, ale i szereg przedmiotów wchodzących w zakres nauczania szkolnego stanowić może dla niektórych wiedzę ezoteryczną - „tajemną".

${ }^{16}$ Czym innym jest np. "kierunek” w znaczeniu potocznym i "kierunek” jako termin $w$ fizyce ( $w$ pierwszym przypadku mamy do czynienia $z$ tym, co fizyk nazwie zwrotem, w drugim z linią wzdłuż której działają siły); czym innym jest działanie moralne w potocznym rozumieniu, czym innym zaś w etyce (potocznie "moralny" oznacza zazwyczaj tyle, co „moralnie dobry”, w etyce zaś stanowi kwalifikację aktów spełnionych w sposób wolny i świadomy, podlegających wartościowaniu etycznemu); czym innym będzie "dobroć” w znaczeniu potocznym, czym innym w elektronice (jako wielkość charakteryzująca układy drgań).

${ }^{17}$ Dla przykładu wymienić tutaj można terminy, takie jak: „substancja” w metafizyce i w chemii; "anamneza” w filozofii i w liturgice, "reakcja” w chemii i w psychologii itp. 
terminologii naukowej jest tworzenie neologizmów, a więc całkowicie nowych słów, najczęściej na bazie wcześniej istniejących. Już Platon w swoim Państwie, przedstawiając historiozoficzną wizję degeneracji ustrojów politycznych, zachwianie równowagi właściwej państwu idealnemu wskutek nadmiernego wzrostu znaczenia klasy wojowników określa mianem "timokracji”, bądź też „timarchii”, zaznaczając, że wprowadza tym samym słowo nowe, gdyż stosownego terminu nie ma jak dotąd w użyciu ${ }^{18}$.

W podobny sposób swoją terminologię pozyskuje również język teologiczny. Można w nim zaobserwować cały szereg wyrażeń zaczerpniętych z języka potocznego, takich jak chociażby „objawienie”, „łaska”, „,wcielenie” czy „,odkupienie”. Niektóre z nich pojawiają się już w samych tekstach biblijnych, co wynika z faktu, że Bóg, przemawiając do człowieka oraz pouczając go o sprawach „nie z tego świata”, pragnąc być przez człowieka zrozumianym, zmuszony był posłużyć się ludzkim językiem, stworzonym przez człowieka w celu nazywania rzeczy przynależących do świata go otaczającego ${ }^{19}$. W tekstach teologicznych spotykamy także szereg neologizmów, które zazwyczaj w sposób skrótowy wyrażają sobą pewną obszerniejszą treść, jak np. "chrystofania” - termin oznaczający zjawienie się Zmartwychwstałego Chrystusa, „kardiognoza” - znajomość sekretów ludzkiego serca, wiedza niedostępna w porządku naturalnym ludziom ani aniołom, "hyperdulia” - szczególna cześć oddawana Matce Najświętszej ze względu na Jej Boże macierzyństwo, przewyższająca cześć należną innym świętym, „perychoreza” - konieczne współprzebywanie Osób Boskich z racji jedności istoty Bożej, itp. Obok podobnych przywołanym powyżej terminów ściśle teologicznych, w sformułowaniach przedstawiających naukę wiary występuje również cały szereg określeń zaczerpniętych z języka nauk filozoficzno-humanistycznych, a także innych, funkcjonujących wciąż w potocznym użyciu.

${ }^{18}$ Zob. tenże, Państwo, VIII, 545 B. Nazwę ustroju, w którym dominują przywódcy wojskowi Platon wywodzi od gr. słowa timos oznaczającego „cześć”, „zaszczyt”, mając na myśli sławę zdobytą na polu bitwy.

${ }^{19}$ Stąd też język Objawienia jest językiem analogii, przybliżającym rzeczy nieznane poprzez podobieństwo do rzeczy znanych i bliskich człowiekowi. Analogiczny charakter języka Objawienia stanowi osobny aspekt „kłopotliwości” tego narzędzia, pominięty w niniejszym tekście. Szersze przedstawienie tego zagadnienia znaleźć można we wcześniejszym moim artykule, Rola filozoficznego pojęcia analogii w uzasadnieniu nauki o rozwoju dogmatów, „Teologia i Człowiek” 14 (2009), s. 113-124. 


\section{DLACZEGO ŁACINA?}

Pośród szeregu argumentów, jakie w literaturze przedsoborowej przywoływano, uzasadniając potrzebę posługiwania się językiem łacińskim jako oficjalnym językiem Kościoła katolickiego, znaleźć można argument istotny $\mathrm{z}$ punktu widzenia naszych rozważań. $\mathrm{W}$ argumencie tym odwoływano się do faktu, że łacina jako język martwy, nie podlega zmianom charakterystycznym dla języków nowożytnych. Przed blisko wiekiem Alojzy Jougan, kapłan i wykładowca teologii na uniwersytecie lwowskim, pisał w ten sposób: ,,język łaciński [...] jako martwy jest niepodatny do przyjmowania jakichkolwiek przekształceń, uporny przeciw skoślawieniu i skażeniu, bierny wobec zakusów nowszego ducha czasu, tak zawsze wrogiego tradycji Kościoła" ${ }^{20}$. W podobny sposób znaczenie języka łacińskiego, jako wyrażającego w sposób „pewny, adekwatny i precyzyjny" prawdy katolickiej wiary, podkreślali autorzy całego szeregu będących w użyciu pomocy katechizmowych.

Ewolucja znaczeń, $\mathrm{z}$ jaką mamy do czynienia w przypadku języków nowożytnych, jest ściśle związana z faktem, że o znaczeniu poszczególnych słów na terenie danego języka rozstrzyga przede wszystkim sposób, w jaki słowa te są używane. To właśnie sposób używania słów sprawia, że niekiedy słowa posiadające identyczną etymologię różnią się między sobą co do swych znaczeń, jak np. „teizm” i „deizm”, czy też „etyka” i „moralność" ${ }^{21}$. Fakt, że rozumienie słów jest ostatecznie zdeterminowane sposobem ich używania, sprawia, że ich wyjaśnianie oparte na wskazaniu etymologii posiadać będzie z punktu widzenia ustalania znaczenia jedynie charakter wstępny i pomocniczy. Sposób używania słów w przypadku języków nowożytnych podlegać może pewnym przeobrażeniom, co sprawia, że zmianie ulegają także ich znaczenia, czego przykładem może być wspomniany wcześniej termin "tolerancja”.

Warto również zauważyć, że zmianom podlegać mogą nie tylko znaczenia poszczególnych słów, ale również związany z nimi ładunek emocjonalny. Kontekst historyczno-kulturowy sprawić może niekiedy, że samo w sobie pozytywne określenie pociągać będzie za sobą ne-

${ }^{20}$ Tenże, Podręcznik teologii pasterskiej, Lwów 1917.

${ }^{21}$ Zarówno "teizm", jak i "deizm" wywodzą się od tego samego słowa - "Bóg” (w j. greckim - theos, po łacinie - Deus); podobnie terminy "etyka" i "moralność" posiadają wspólną etymologię nawiązującą do słów oznaczających "zwyczaj”, "obyczaj” (gr. ethos oraz łac. mos, -ris). Znaczeniowo jednak różnią się znacznie między sobą. 
gatywne konotacje ${ }^{22}$, jak chociażby używany w niedalekiej przeszłości tytuł „towarzysz”. Wydaje się, że podobny los dzieli współcześnie tak ważny i nośny w naukach filozoficzno-teologicznych termin, jak „cnota”. Przedstawione przez Zbigniewa Herberta poetyckie wyobrażenie cnoty jako „płaczliwej starej panny w okropnym kapeluszu”, od której „wionie zapach naftaliny”, „nieznośnej w swoim uporze”, a zarazem "śmiesznej jak strach na wróble", wydaje się dobrze oddawać odczucia, przez wielu współczesnych $\mathrm{z}$ terminem tym kojarzone ${ }^{23}$. Zapewne jedynie nieliczni wiedza, że polskie słowo „cnota”, to odpowiednik greckiego arete, oznaczającego sprawność odnoszącą się do rozmaitych umiejętności, sztuk, sportu, w szczególności zaś do życia moralnego ${ }^{24}$. Również łaciński termin virtus, kojarzony przede wszystkim z męstwem, pozostaje daleki od przywołanego wyobrażenia płaczliwej starej panny.

Obok ewolucji znaczeń poszczególnych słów oraz zmian zachodzących w obrębie ich emocjonalnych konotacji, język daje się poznać jako narzędzie „kłopotliwe” również wskutek niedoskonałości przekładów dokonywanych z jednego języka na drugi. Pomijamy tutaj rzecz jasna mankamenty tłumaczeń, będące skutkiem ludzkich zaniedbań i niekompetencji, koncentrując się jedynie na pewnych wewnętrznych ograniczeniach, jakie pociąga za sobą sama natura języka jako takiego. Jak zostało już wcześniej wspomniane, w myśl swej definicji język jest systemem znaków umownych odpowiadających pojęciom, jakie człowiek tworzy sobie w procesie poznania abstrakcyjnego i posiada w swoim intelekcie. Składające się na język poszczególne słowa stanowią zatem swego rodzaju metryki zbiorów desygnatów, do których odnoszą się poszczególne pojęcia ${ }^{25}$. Wyjaśnienie znaczenia jakiegoś słowa to zatem nic

${ }^{22}$ Przez "konotację" rozumie się zazwyczaj pewien ładunek afektywny, stanowiący element subiektywny i zmienny znaczenia. Pojęcie „konotacji” pozostaje w opozycji do pojęcia "denotacji", jako elementu stałego, obiektywnego znaczenia słowa. Zob. A. Pisarska, T. Tomaszkiewicz, Wspótczesne tendencje przekładoznawcze, Poznań 1998, s. 94.

${ }^{23}$ Por. Pan Cogito o cnocie, w: Z. Herbert, Raport z oblężonego Miasta $i$ inne wiersze, Wrocław 1992, s. 36-38.

${ }^{24}$ Termin arete pojawia się już u początków refleksji etycznej, za której ojca uchodzi powszechnie Sokrates. Jego uczniowi Platonowi zawdzięczamy pierwszy w dziejach katalog cnót, znanych w późniejszej tradycji łacińskiej pod nazwą ",kardynalnych", od łac. cardo, -inis - „zawias" (cnoty kardynalne pełnią bowiem niejako funkcję "zawiasów", na których opiera się życie moralne człowieka). Obszerną klasyfikację cnót przedstawia w swojej etyce również Arystoteles.

${ }^{25} \mathrm{~K}$. Ajdukiewicz ujmuje tę rzecz następująco: „Przedmioty oznaczone przez pewną nazwę zowią się desygnatami tej nazwy bądź desygnatami pojęcia będącego 
innego, jak określenie czym jest przedmiot, który dane słowo oznacza. Problem $w$ tym, że obok odpowiadających sobie w różnych językach słów, wyznaczających pokrywające się ze sobą zbiory desygnatów, istnieją również słowa, których przekład nastręczać będzie pewnych trudności ze względu na fakt, że zbiór desygnatów odpowiadających terminowi użytemu w tłumaczeniu, częściowo tylko pokrywać się będzie ze zbiorem desygnatów odpowiadających terminowi zawartemu w tekście oryginalnym lub odwrotnie. O ile bowiem można w sposób precyzyjny i jednoznaczny dokonywać przekładu słów takich, jak chociażby wspomniany już wcześniej „pies”, o tyle nie da się tego równie łatwo uczynić w przypadku np. słowa „zabijać”, o czym świadczą perypetie związane z przekładem tekstu piątego przykazania Dekalogu ${ }^{26}$.

Przykładem podobnie "kłopotliwego" tłumaczenia są zresztą również tak znane określenia, jak Stary i Nowy Testament. Dość wspomnieć, że kilkoro spośród grupy młodych ludzi poproszonych o wyjaśnienie znaczenia tych określeń, miało z zadaniem tym spory kłopot, łamiąc sobie głowę, czyją to "ostatnią wolę" stanowi Stary Testament. W przypadku Nowego, rzecz wydawała się bowiem prosta - ze względu na opisaną w nim śmierć Chrystusa Pana, skojarzenie wydawało się stosunkowo oczywiste ${ }^{27}$.

\section{KŁOPOTLIWE SŁOWO „JEST" ORAZ NIESZCZĘSNE „SERCE”}

Zapewne niejeden spośród duszpasterzy czy katechetów miał okazję usłyszeć prowokujące stwierdzenie: „A po co chodzić do kościo-

jej znaczeniem. Zbiór wszystkich desygnatów jakiejś nazwy stanowi jej zakres. Zbiór wszystkich desygnatów jakiegoś pojęcia stanowi zakres tego pojęcia". Tenże, Zarys logiki, Warszawa 1960, s.15-16.

${ }^{26}$ Polski czasownik ,zabijać” posiada niezwykle szeroki zakres znaczeń, podczas gdy użyty w tekście Dekalogu czasownik hebrajski razah, nigdzie w Piśmie Świętym nie zostaje odniesiony do zabijania zwierząt, bądź też do sytuacji walki zbrojnej. Stąd też będące dziełem paulistów najnowsze wydanie Biblii tłumaczy zawarty w piątym przykazaniu zakaz, jako „nie będziesz mordowal”.

${ }^{27}$ Użyte w powyższych określeniach słowo "testament" stanowi spolszczoną wersję łacińskiego testamentum, będącego przekładem greckiego terminu diatheke, posiadającego znaczenie podwójne - dokumentu ostatniej woli umierającego oraz dokumentu zawartego układu, przymierza. Greckie tłumaczenie słowem diatheke oddało z kolei hebrajski termin berit, oznaczający po prostu „przymierze”. Wspomniane nieporozumienie pociąga za sobą fakt, że używane w języku polskim słowo „testament" zwykło być współcześnie odnoszone wyłącznie do przedśmiertnego rozporządzenia. Zob. T. Penar, Wstęp ogólny do Pisma Świętego, Pelplin 1986, s. 10. 
ła, przecież Pan Bóg jest wszędzie". Powyższa wypowiedź przynależy do żelaznego arsenału, jakim posługują się zazwyczaj osoby usiłujące usprawiedliwić $\mathrm{w}$ ten sposób swoje lenistwo i religijną obojętność. Warto zwrócić uwagę na fakt, że źródłem nieporozumienia, jakie leży u podstaw sformułowanej $\mathrm{w}$ ten sposób wypowiedzi, jest niejednoznaczność tak podstawowego we wszystkich językach słowa, jakim jest czasownik wyrażający istnienie, obecność. Mówimy: „on j e s t tutaj”, wskazując na człowieka, który fizycznie, dosłownie, w sposób materialny znajduje się na wyciągnięcie naszej ręki, którego możemy dotknąć, uściskać, podać mu rękę. Ktoś mówi „to j e s t mój syn, moja córka”, pokazując znajomym zdjęcie, które nosi przy sobie, albo trzyma oprawione na swoim biurku. Ktoś inny wyjeżdżając, pociesza bliską sercu osobę zapewniając ją: „pamiętaj, że zawsze j e s t e m z tobą”. Nietrudno zauważyć, że odmieniane w powyższych wypadkach słowo ,jest", w każdym z nich oznacza coś odmiennego. Nie jest przecież tym samym żywa obecność najbliższych i ich obecność na przysłanej przez nich fotografii, podobnie jak faktu duchowej obecności, wyrażającej się w towarzyszeniu komuś myślami czy modlitwą, nie da się postawić na równi z przebywaniem $\mathrm{z}$ kimś w dosłownym znaczeniu.

Słowo ,jest" zwykliśmy zatem odnosić do form obecności różniących się między sobą i nawzajem do siebie niesprowadzalnych. Świadomość ta winna towarzyszyć nam zatem również, kiedy słowem tym wyrazić pragniemy fakt Bożej obecności w świecie. W innym bowiem sensie Bóg jest obecny „wszędzie”, w innym zaś w Najświętszym Sakramencie. $W$ pierwszym przypadku wszechobecność Boga wyraża się w tym, że jest On przyczyną sprawczą stwórczą całego świata, co więcej - nieustannie podtrzymującą ten świat $\mathrm{w}$ istnieniu, że przenika całość stworzenia swą Boską wszechwiedzą, oraz że czuwa nad nim jako kierująca losami wszechrzeczy Opatrzność. Nie jest jednak Bóg, jak błędnie utrzymują panteiści, przyczyną materialną świata, jego tworzywem, stąd też wszechobecność Boga nie ma charakteru materialnego. Obecność sakramentalna $\mathrm{w}$ konsekrowanych postaciach chleba i wina posiada natomiast taki właśnie wymiar, wiąże się bowiem ściśle z tajemniczym wejściem Boga w materię, tak że, jak naucza Sobór Trydencki, „Pan nasz Jezus Chrystus, prawdziwy Bóg i prawdziwy człowiek, znajduje się prawdziwie, rzeczywiście i substancjalnie (vere, realiter et substantialiter) pod postaciami owych widzialnych rzeczy"28.

${ }^{28}$ Dekret o Najświętszym Sakramencie z 1551 r., rozdz. I. Zob. Denz., 874. Wydaje 
Z innego typu niejednoznacznością spotykamy się w przypadku słowa "serce", tak często obecnego zarówno w tekstach Objawionych, w opracowaniach teologicznych, jak i w używanym na co dzień języku. Czytamy zatem i słyszymy niejednokrotnie o "skruszonym sercu”, ,sekretach serca”, „sercu kochającym” itp. Warto zauważyć, że we wszystkich wymienionych przypadkach słowo „serce” pojawia się jedynie jako pewna metafora, odnosząca się do rzeczywistości innej aniżeli ta, która stanowić będzie przedmiot zainteresowania kardiologii, zajmującej się ex professo sercem, $\mathrm{w}$ jego znaczeniu dosłownym. Problem w tym, że rozumienie metafory serca nie jest jednolite ze względu na swoje kulturowe uwarunkowania.

$\mathrm{W}$ tekstach biblijnych serce, podobnie zresztą jak i inny anatomiczny narząd wewnętrzny człowieka - nerki, wyobraża to wszystko, co stanowi jego najgłębszą istotę, a więc odnosi się przede wszystkim do ludzkiej sfery duchowej - intelektualnej i wolitywnej. O takim rozumieniu słowa "serce" świadczyć mogą chociażby liczne teksty zawarte w Psalmach, w których pojawia się motyw "myśli serca" ${ }^{\prime 2}$. Do metafory serca, jako myślącego podmiotu, nawiązuje także sam Chrystus Pan, stawiając uczonym w Piśmie oraz faryzeuszom pytanie: "Co za myśli nurtują $\mathrm{w}$ sercach waszych?" ${ }^{\prime 30} \mathrm{~W}$ podobnym duchu wypowiada się Ewangelista o Matce Zbawiciela, stwierdzając, że „zachowywała te sprawy i rozważała je w swoim sercu" ${ }^{\prime \prime 1}$. Powyższe teksty, jak i wiele innych im podobnych, upoważniają do stwierdzenia, że $\mathrm{w}$ myśl antropologii biblijnej serce stanowi siedlisko świadomej, rozumnej i wolnej osobowości człowieka, przestrzeń, w której zapadają ludzkie decyzje, i w której człowiek spotyka się z Bogiem ${ }^{32}$.

O ile słowo „nerki” w kulturze współczesnej całkowicie zatraciło swój sens metaforyczny i nie pojawia się zasadniczo poza tekstami z za-

się, że na niejednoznaczny charakter słowa ,jest” zwrócić warto uwagę również w kontekście liturgicznym. Obecność Chrystusa w osobie sprawującego liturgię eucharystyczną kapłana, który działa, jak wiemy, in persona Christi, czy też obecność Chrystusa, której symbolem jest ołtarz, na którym sprawowana jest Najświętsza Ofiara, nie dają się porównać z "prawdziwą, realną i substancjalną" obecnością Zbawiciela pod postacią konsekrowanego chleba, przechowywanego $\mathrm{w}$ tabernakulum.

${ }^{29}$ Zob. np. Ps 19, 15; Ps 35, 25; Ps 49, 4; Ps 73, 7; Ps 77, 7.

${ }^{30}$ Łk 5, 22.

${ }^{31}$ Łk 2, 19.

${ }^{32}$ Por. X. Leon-Dufour (red.), Stownik teologii biblijnej, tłum. K. Romaniuk, Poznań 1990. 
kresu biologii i medycyny, o tyle „serce” nadal funkcjonuje jako nośna metafora, chociaż jej znaczenie uległo istotnej modyfikacji. We współczesnym języku słowo „serce”, odmiennie aniżeli w Biblii, kojarzone jest bowiem przede wszystkim ze sferą ludzkiego życia uczuciowego ${ }^{33}$. Fakt ten sprawia, że zdarza się niejednokrotnie, iż odczytując teksty Objawione według klucza, jaki narzuca nam dzisiejsze rozumienie metafory serca, rozmijamy się $\mathrm{w}$ istotny sposób z zawartym w nich przesłaniem, fałszywie interpretując cały szereg ważnych wskazań, odnoszących się do tak fundamentalnych ludzkich aktów, jak nawrócenie, wiara, modlitwa, żal za grzechy itp. ${ }^{34}$

\section{PODSUMOWANIE}

Jan Paweł II przypomina w swej encyklice Fides et ratio, że ważny wkład, jaki filozofia wnosi w uprawianie teologii, obejmuje refleksję nad ludzkim poznaniem i porozumiewaniem się, któremu służy narzędzie, jakim jest język ${ }^{35}$. Narzędziem tym zmuszony jest bowiem posługiwać się również Kościół, przekazując niezmienną prawdę Bożego Słowa, które, jak poucza Ojciec Święty, nie zostało skierowane „do jednego tylko narodu lub do jednej tylko epoki"36. Refleksja filozoficzna ma zatem służyć zachowaniu absolutnego i uniwersalnego charakteru prawdy, wyrażanej przy użyciu narzędzia, podlegającego licznym ograniczeniom historycznym i kulturowym.

Celem naszych rozważań było zwrócenie uwagi na niektóre ze wspomnianych ograniczeń, jakim podlega język, w przekonaniu, że ich pogłębiona świadomość przyczynić się może do bezpieczniejszego posługiwania się wspomnianym narzędziem, które, ze względu na trudności związane z jego używaniem, pozwoliliśmy sobie określić mianem narzędzia „kłopotliwego”.

${ }^{33}$ Zob. tamże.

${ }^{34}$ Jeśli bowiem np. św. Paweł pisze, że „sercem przyjęta wiara prowadzi do usprawiedliwienia" (Rz 10, 10), ma na myśli wewnętrzne nastawienie ludzkiego intelektu i woli, nie zaś jakieś „uczucie wiary”. Pomylenie tych dwóch porządków prowadziło i prowadzi w dziedzinie religijnej do poważnych błędów. „Wzniosłe uczucia - jak poucza Katechizm Kościoła Katolickiego - nie decydują ani o moralności, ani o świętości osób". Tamże, 1767.

35 Tamże, 65.

${ }^{36}$ Tamże, 95. 
Podstawowa trudność dotycząca języka, jakim posługuje się teologia, wynika już z samego faktu, że nadprzyrodzone Objawienie dokonało się za pomocą metafor, po które sięgnął Bóg, by posługując się narzędziem, które człowiek wypracował sobie do opisu otaczającej go rzeczywistości ziemskiej, pouczyć ludzkość o sprawach poza tę rzeczywistość wykraczających. Problem analogicznego charakteru języka objawienia oraz konsekwencji wynikających zeń dla uprawiania samej teologii, przedstawiony wcześniej w formie osobnego artykułu, został $\mathrm{w}$ niniejszym opracowaniu pominięty.

Zwróciliśmy natomiast uwagę na fakt ograniczeń wynikających z ewolucji znaczeń poszczególnych słów oraz zmienności kojarzonego $\mathrm{z}$ nimi ładunku emocjonalnego. Wskazaliśmy również na niektóre problemy związane z przekładem terminów, których zakresy w poszczególnych językach różnią się pomiędzy sobą, a także na "kłopotliwość" wyrażeń, których niejednoznaczność pozostaje bądź to wynikiem zmieniającego się kontekstu wypowiedzi, w jakim są one używane (słowo ,,jest"), bądź też, na zmianę znaczenia których rzutuje szerszy kontekst kulturowy (metafora „serca").

\section{SPRACHE ALS EIN PROBLEMATISCHES WERKZEUG IM THEOLOGIETREIBEN}

\section{ZUSAMMENFASSUNG}

Der Papst Johannes Paul II erinnert in seiner Enzyklika Fides et ratio daran, dass ein erheblicher Beitrag, der die Philosophie zu der Theologie leistet, eine Reflexion über menschliche Erkenntnis und Verständigung umfasst, deren Werkzeug die Sprache ist. Auch die Kirche ist nämlich gezwungen, sich dieses Werkzeugs zu bedienen, um die unveränderliche Wahrheit des Wortes Gottes, das nach der Lehre des Papstes nicht lediglich „an ein Volk oder eine Epoche gerichtet wur$\mathrm{de}^{\prime \prime}$ zu übermitteln. Die philosophische Reflexion sollte also der Einhaltung eines absoluten und universalen Charakters der Wahrheit, die mit Hilfe eines den zahlreichen historischen und kulturellen Einschränkungen unterliegendem Werkzeugs ausgedrückt wird, dienen.

Ziel unserer Betrachtungen war die Lenkung der Aufmerksamkeit auf manche der erwähnten Beschränkungen der Sprache, mit der Überzeugung, dass solches vertieftes Bewusstsein zu einer mehr sicheren Benutzung dieses Werkzeugs, dass wir im Hinblick auf seine Anwendungsschwierigkeiten als "problematisches" Werkzeug bezeichneten, beitragen kann.

Die grundsätzliche Schwierigkeit der Sprache, der sich Theologie bedient, erfolgt schon allein aus der Tatsache, dass die übernatürliche Offenbarung mithilfe 
von Metaphern erfolgte, die Gott gewählt hat, um die Menschheit mithilfe von dem vom Menschen zur Beschreibung der ihn umgebenden irdischen Wirklichkeit ausgearbeiteten Werkzeug über die diese Realität überschreitenden Sachen zu belehren. Das Problem des analogen Charakters der Offenbarungssprache und der sich daraus hervorgehenden Folgen für das Theologietreiben selbst, das früher in Form eines getrennten Artikels dargestellt worden ist, wurde in dieser Bearbeitung nicht berücksichtigt.

Wir haben dagegen die Aufmerksamkeit auf die sich aus der Bedeutungsentwicklung von einzelnen Wörtern und Veränderlichkeit der mit ihnen assoziierten Emotionen ergebenden Einschränkungen gemacht. Ferner haben wir auf manche Probleme bei der Übersetzung der Begriffe, deren Bedeutungsumfang in einzelnen Sprachen unterschiedlich ist, sowie auf die Problematik der Anwendungen, deren Uneindeutigkeit die Folge eines sich verändernden Kontextes der Aussage, in dem sie angewandt wird (das Wort „ist") oder auf deren Änderung der Bedeutung ein weiterer kultureller Kontext (Metapher des Herzens) einen Einfluss hat, hingewiesen. 